\title{
Removal of Heavy, Metals from Municipal Wastewater Sludge Under the Effect of Electric Current Application
}

\author{
Hazem I. Saleh ${ }^{1}$, Mohamed A.M.O. ${ }^{2}$ \\ r.t. \\ ${ }^{\prime}$ Civil Ėngineering Dept., Menoufia Univ. Egypt \\ ${ }^{2}$ Civil Engineering Dept., McGill Univ. Canada
}

\begin{abstract}
The application of an electric current was used to investigate the removal of heavy metals from a dewatered wastewater municipal sludge. Electric current application enabled the removal of Nickel, Chromium, Zinc, and Copper from sludge samples. Distilled water was introduced to the electro-kinetic cell used for the study to compensate for cathodic effluent. As a consequence of electric current application, the amount of collected cathodic effluent, $\mathrm{pH}$ fluctuations, and electrical conductivity variations of the collected cathodic effluent were investigated and found to be governing factors for the application of the process. Approximately $40 \%$ of Nickel removal was achieved while removal of other investigated metals ranged from 5 to $8 \%$ during the experimental run. Removal rates of different metals and power consumption during the experimental run were also investigated.
\end{abstract}

\section{Introduction}

Sludge generation from wastewater treatment plants is expected to be permanently growing with population growth, enhancement of treatment units efficiency, the construction of new plants and the expansion of existing ones. Use and disposal of municipal wastewater sludge include landfilling, incineration, land application, composting as shown in Table I (U.S. EPA, 1987).

Manuscript received from: Dr. Hazem I. Saleh at: $26 / 4 / 1998$

Accepted at: $19 / 7 / 98$

Finginecring research bulletin, Vol. 21 No.3 1998

Menoutiya University, Faculiy of Ingineering

Shebin Fl-Kom, Egypt, ISSN. $1110-1180$ 
The main sludge constituents that can be potentially harmful to crops, animals and humans are: (1) heavy metals as $\mathrm{Cd}, \mathrm{Pb}, \mathrm{Cu}, \mathrm{Zn}$ and $\mathrm{Ni}$; (2) Regulated organics as polychlorinated biphenyl and dichloro-methane; (3) Pathogens as bacteria, virus, protozoa and helminths; and finally (4) excess nutrients as nitrogen, phosphate, and potassium. Primary and secondary sludge commonly undergo further treatment, i.e., thickening, dewatering, aerobic or anaerobic digestion in order to reduce sludge volume and pathogens content. The amount and characteristics of sludge vary from one treatment plant to another depending on the characteristics of the incoming sewage, either municipal or mixed with industrial waste, and the nature of the treatment process. Typical ranges of heavy metals concentration in municipal wastewater sludge are shown in Table 2.

An investigation of heavy metals partitioning showed that metal speciation varied significantly from one sludge to another and that the organic and residual fractions were the principal metal binding phases, this was consistent in sludges from different climatic zones as in Canada, U.S. and U.K. (Ravishankar et al., 1994). A similar study suggested four main components of the sludge: particulates, biofloc, colloid, and soluble. The studied copper, nickel, and zinc were held: (1) $85-95 \%$ in the biofloc (bacterial detritus), 5-15\% on the mineral grains and organic fragments of the particulate fractions, and (3) not more than $3 \%$ in soluble and colloidal organic matter (MacNicol and Beckett, 1989). Particulate form of heavy metals may exist in either hydroxide form, organic complexes, and/or sulphide precipitates (Caldwell and Anderson, 1993).

Several methods were investigated for metals removal from sludge as by lowering the $\mathrm{pH}$ (Fristoe and Nelson, 1983), or through indigenous sulfuroxidizing bacteria present in the sludge that decreases sludge $\mathrm{pH}$ due to sulphate generation by sulphate producing bacteria (Sreekrishnan et al., 1993). While temperature variation affected the rate of bacterial growth thus the degree of $\mathrm{pH}$ reduction, it was found that at constant $\mathrm{pH}$ metal solubilization was the same (Tyagi et al., 1994). Electric current application to municipal sludge was thus used for reducing the $\mathrm{pH}$ of the sludge pore fluid and was beneficial in heavy metals removal. The acid front generated due to hydrolysis and hydrogen ions generation advanced towards the cathode faster than the transport of base front toward the anode resulting in a decrease in the $\mathrm{pH}$ of the cathodic effluent (Mohamed and Saleh, 1997).

Electric potential was also applied for heavy metals removal from contaminated sites (Alshawabkeh and Acar, 1996; Eykholt and Daniel). It is anticipated that the amount of metal removal from the sludge will directly increase the period of sludge application to land where cumulative metals concentration is the governing factor. The recommended cumulative limits for 
metals applied to agricultural land in $\mathrm{kg} / \mathrm{ha}$ will differ with the type of soil and shall not exceed $560,280,140,140$, and 5 for $\mathrm{Pb}, \mathrm{Zn}, \mathrm{Cu}, \mathrm{Ni}$, and $\mathrm{Cd}$ respectively for a soil cation exchange capacity less than $5 \mathrm{meq} / 100 \mathrm{~g}$ as would be the case in soils with low clay content mainly from kaolinite (U.S. EPA, 1983). In this paper, the removal of heavy metals from the studied sludge was investigated showing effluent $\mathrm{pH}$ variation, rates of metals removal and electric power consumption.

\section{Materials and Methods}

Municipal wastewater sludge was obtained from the City of Montréal wastewater treatment plant applying a physico-chemical treatment process using ferric chloride and anionic polymer for the sedimentation process. Sludge samples were preserved at $4^{\circ} \mathrm{C}$, heavy metals concentration in collected sludge samples are shown in Table 3. Electric potential was applied to the sludge using regulated DC power supply connected to the anode and cathode of the plexiglass cylindrical cell $(50 \mathrm{~mm}$ diameter, $75 \mathrm{~mm}$ height). A constant voltage of $26.5 \mathrm{~V}$ was applied to the cell filled with approximately 200 grams of dewatered sludge.

Gas generation occurred in the cell and this evoked the need of using a hydraulic head arbitrarily chosen $300 \mathrm{~mm}$ to ensure continuous flow of distilled water to the cell thus preventing back flow. Distilled water was introduced to the anodic site of the cell and the effluent was collected at the top of the cathodic site to allow gas release with the flow. The experimental run was conducted on fresh sludge samples under coupled hydrodynamic and electroosmotic effects.

Metals concentration in the collected cathodic effluent were analyzed using Perkin Elmer atomic absorption spectrophotometer 3110 (AAS). Nickel, chromium, zinc, copper, cadmium, and lead concentrations that are regulated heavy metals of concern for land application of sludge were investigated, other related pirameters were also determined.

\section{Results and Discussion}

The results of the experimental investigation conducted in this research work represents a most successful case for heavy metals removal from municipal sludge using electroosmotic potential compared with several cases previously investigated by the authors. Different conditions of sludge age and acid addition to help mobilizing the precipitated metals from the sludge were previously investigated and the results were accordingly published (Mohamed and Saleh, 1997). While in this study a close approach to the most successful case of study for heavy metals removal was conducted showing rates of heavy 
metals collection at the cathodic site of the electro-kinetic cell used through the experiments.

The amount of cathodic effluent collected under the effect of electric current application and the aforementioned experimental conditions is shown in Figure 1. The amount of collected effluent decreased with time till approximately 50 hours of current application, where the collected volume was very low and was considered as the end of the experimental run: Meanwhile, the variations in $\mathrm{pH}$ of the collected cathodic effluent shown in Figure 2 showed a sharp decrease at the first phase of operation due to excessive gas generation upon hydrolysis of pore fluid near the electrodes. The flow $\mathrm{pH}$ reached 4.20 at its lowest value and the removal of heavy metals was attributed to this $\mathrm{pH}$ lowering within the sludge pore fluid resulting in the dissolution of the metals from the precipitate form within the sludge. Gas generation decreased with time and therefore cathodic effluent $\mathrm{pH}$ started to increase to reach around 6.00 at the end of the experimental run consequently the removal of heavy metals was expected to be adversely affected.

The cumulative electrical conductivity shown in Figure 3 converged to a limiting value indicating less dissolved solids removal from the system. This value appeared to be in accordance with the calculated electrical conductivity of the sample discussed hereafter. Variations in electrical conductivity with time shown in Figure 4 also indicated a sharp decrease in dissolved solids concentration in the effluent that may be a limiting factor in the operation of such system that is also influenced by $\mathrm{pH}$ reduction.

Analysis of heavy metals content of the raw dewatered sludge showed that cadmium was not detected in the sludge. As this metal is of most concern in land application processes regarding its potential to present phytotoxicity problems, strict and controlled discharge limits are possibly the cause of its absence in the sludge. Concentrations of all other studied heavy metals were within the range for typical sewage sludge shown in Table 2.

Removal of Nickel, Chromium, Zinc, and Copper from the sludge was successfully achieved and their cumulative concentrations in the cathodic effluent are shown in Figures 5 \& 6 . Rates of metals removal tend to decrease with time except for Nickel that was relatively constant through the experimental run. While these curves did not converged to be parallel to the abscissa thus reflecting excessive removal of these metals, other governing factors as low cathodic effluent collected and rising $\mathrm{pH}$ of the system may imply termination of the electric current application. Removal rates for $\mathrm{Ni}$ reached approximately $40 \%$ while $\mathrm{Cr}, \mathrm{Zn}$ and $\mathrm{Cu}$ removal ranged from $5 \%$ to $8 \%$ 
Field strength, current intensity, and duration of application are all important parameters in the electrokinetic analysis of metals removal and were used to estimate the power consumption. The system run 53.5 hours during which $1985 \mathrm{ml}$ were collected, the yield was calculated as the total flow collected per unit power consumption as follows:

Power consumed $P=I V=19.80$ Watt (summation of variable $I$ by $V$ )

Resistance of the sample $R=V^{2} / P=35.47 \mathrm{Ohm}$

Electrical conductivity of the sample $\sigma=\mathrm{L} /\left(\mathrm{A}^{*} \mathrm{R}\right)=0.255 \mathrm{~S} / \mathrm{m}=2.55 \mathrm{mS} / \mathrm{cm}$

Total Power Consumption (TPC) $=1.06 \mathrm{kWhr}$

Yield $=\mathrm{Q} / \mathrm{TPC}=1.985 / 1.06=1.87$ liter $/ \mathrm{kWhr}$

where $\mathrm{P}=$ power consumption (Watt), $\mathrm{i}=$ current intensity (Ampere), $\mathrm{V}=$ current voltage (Volt), $\mathrm{R}=$ sample resistance $(\mathrm{Ohm}), \sigma=$ electrical conductivity $(\mathrm{S} / \mathrm{m}), \mathrm{L}=$ sample length $(\mathrm{m})$, and $\mathrm{A}=$ cross sectional area of sample $\left(\mathrm{m}^{2}\right)$. Calculated electrical conductivity of the sample was similar to the measured value to which the experimental run diverted thus correlating between experimental investigation and the expected cell resistance as calculated.

\section{Conclusions}

Electro-osmotic potential applied to municipal wastewater sludge successfully led to the removal of heavy metals as influenced by $\mathrm{pH}$ decrease within the sludge. The amount of cathodic effluent and the variation in effluent $\mathrm{pH}$ and electric conductivity were all investigated and were found to represent limiting parameters in the application of the system to sludge for heavy metals removal. Meanwhile, the amounts of $\mathrm{Ni}, \mathrm{Cr}, \mathrm{Cu}$, and $\mathrm{Zn}$ collection in the cathodic effluent were quantified to show their rates of removal under the investigated experimental conditions and Nickel mobility was found to be higher than all other studied metals. The system power consumption was estimated, also the calculated and measured electric conductivity value for the sludge sample in the electro-kinetic cell were found to be matching. 


\section{References}

Alşhawabkeh, A.N., and Acar, Y.B. (1996) "Electrokinetic Remediation. IIITheoretical Model" Journal of Geotechnical Engineering Vol. 122, No. 3, March 1996.

Caldwcll, R.J., and Anderson, B.C. (1993) "Alkaline Solubilization of Wastewater Sludges: Fate of Trace Metals" 1993 Joint CSCE-ASCE National Conference on Environmental Engineering, pp. 429 - 436.

Eykiholt, G.R, and Daniel, D.E. (1994) "Impact of System Chemistry on Electroosmosis in Contaminated Soil" Journal of Geotechnical Engineering, Vol. 120, No. 5, May 1994.

Fristoe B.R., and Nelson P.O. (1983) "Equilibrium Chemical Modelling of Heavy Metals in Activated Sludge" Wat. Res. 17, pp. 771-778.

MacNicol R.D.. and Beckett P.H. (1989) "The distribution of heavy metals between the prinuipal components of digested sewage sludge" Wat. Res. Vol. 23, No.2. pp. 199-206.

Mohamed, A.M.O,, Saleh H.I. (1997) "Heavy Metals Removal from Municipal Wastevater Sludge for Land Application Management" Procecdings, Geoenvironmental Engineering, Cardiff U.K., Sep. 16-18 pp. 449-454.

Ravishankar B.R., Auclair J.-C., and Tyagi R.D. (1994) "Partitioning of heavy metals in some Quebec municipal sludges" Water Poll. Res. J. Canada, Vol. 29, No. 4. pp. $457-470$.

Sreckrishnan T.R., Tyagi R.D., and Campbell P.G.C. (1993) "Kinetics of heavy mctals bioleaching from sewage sludge - I. Effects of process parameters" Wat. Res. vol. 27, No. 11, pp. 1941-1651, 1993

Tyagi R.D., Srcekrishnan T.T., Blais J.F., and Campbell P.G.C. (1994) "Kinetics of heavy metal bioleaching from sewage sludge - III. Temperature effect" Wat. Res. Vol. 28, No. 11, pp. 2367-2375.

U.S. EPA. (1983) "Process Design Manual: Land application of municipal sludge, Municipal Environmental Research Labortatory" EPA-625/1-83-016.

U,S.,EPA. (1987) "Design Manual: Dewatering Municipal Wastewater Sludges" Office of Research and Devclopment Washington DC 20460, EPA/625/1$87 / 014$, p. 193. 
Table 1 Sludge Disposal/Utilization Practices (\% of dry sludge solids) for Different Sizes of Wastewater Treatment Plants

\begin{tabular}{lllll}
\hline Plant Size & Small & Medium & Large & Total \\
Landfill & 31 & 34 & 12 & 15 \\
Incineration & 1 & 1 & 32 & 27 \\
Land application & 39 & 17 & 21 & 24 \\
Marketing & 11 & - & 19 & 18 \\
Ocean Disposa! & 1 & $\underline{10}$ & 4 & 4 \\
Other & $\underline{100}$ & & 100 & 12 \\
& & & & 100 \\
\hline
\end{tabular}

Source: U.S. LPA, 1987

Table 2 Týpical lleavy Metals Concentration in Sewage Sludge ( $\mathrm{mg} / \mathrm{kg}$ )

\begin{tabular}{lclll}
\hline & & & & \\
\hline & & & & \\
$\mathrm{Cu}$ & & Range & Median & Mean \\
$7 \mathrm{n}$ & 205 & $84-10,400$ & 850 & 1,210 \\
$\mathrm{Ni}$ & 208 & $101-27,800$ & 1,740 & 2,790 \\
$\mathrm{~Pb}$ & 165 & $2-3,520$ & 82 & 320 \\
$\mathrm{Cd}$ & 189 & $13-19,700$ & 500 & 1,360 \\
\hline
\end{tabular}

Source: U.S. EPA, 1983

Table 3 Sludge Heavy Metals Concentration

\begin{tabular}{llll}
\hline $\mathrm{nl}$ & $677(\mathrm{mg} / \mathrm{kg})$ & $\mathrm{Cr}$ & $6875(\mathrm{mg} / \mathrm{kg})$ \\
$\mathrm{Pb}$ & $1330(\mathrm{mg} / \mathrm{kg})$ & $\mathrm{Ni}$ & $1497(\mathrm{mg} / \mathrm{kg})$ \\
$\mathrm{Cu}$ & $1206(\mathrm{mg} / \mathrm{kg})$ & $\mathrm{Cd}$ & Not Detected \\
$\mathrm{pll}$ & 6.74 & Solids content $30 \%$ \\
\hline
\end{tabular}




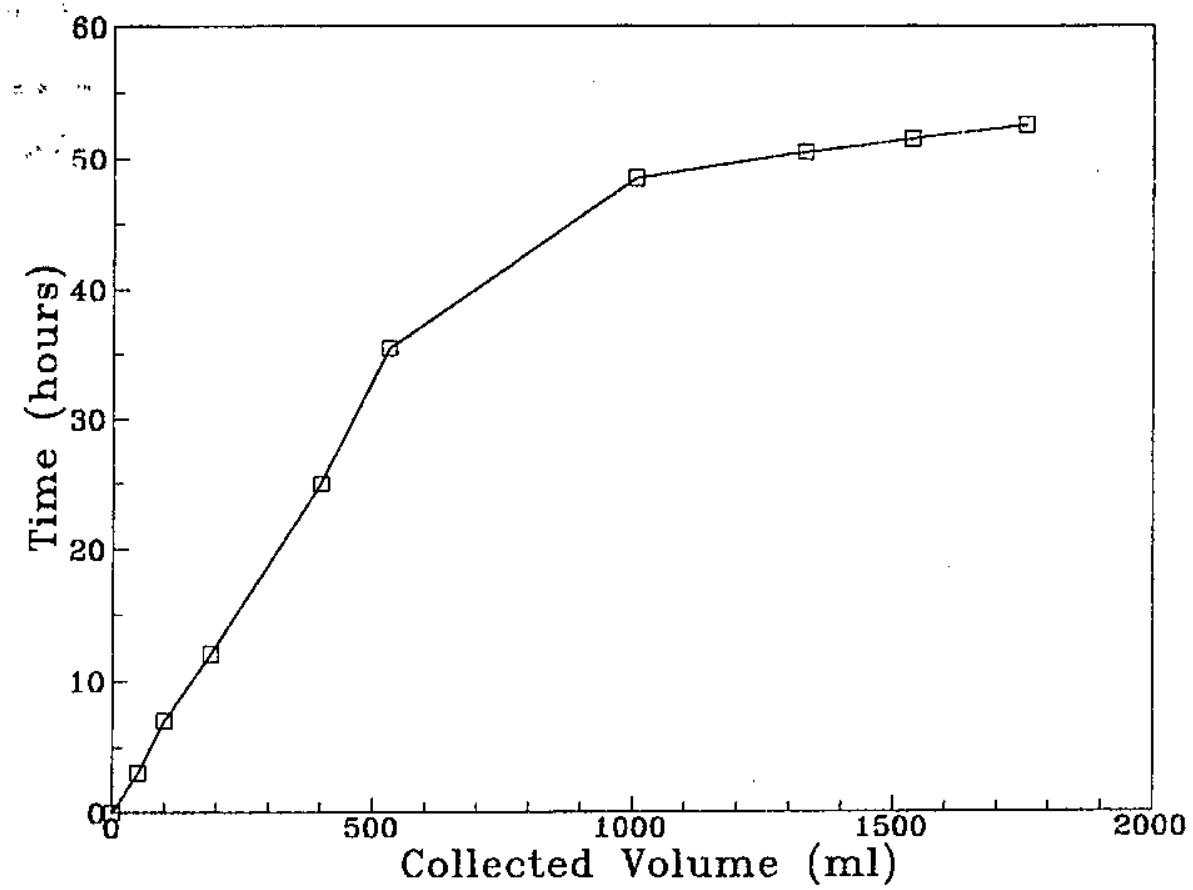

Figure 1 Cell collected cathodic effluent as a function of time

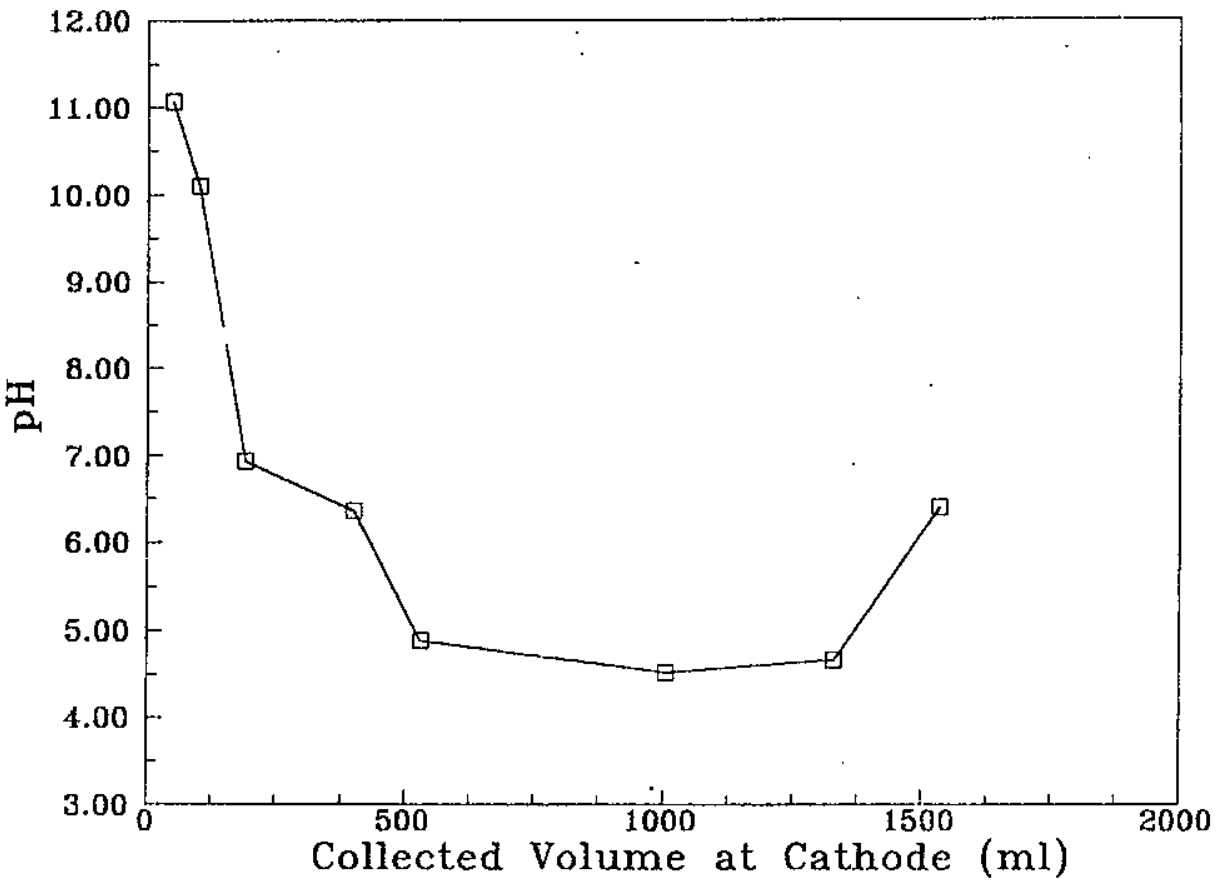

Figun 2 pll ariation with collected cathodic elluent 


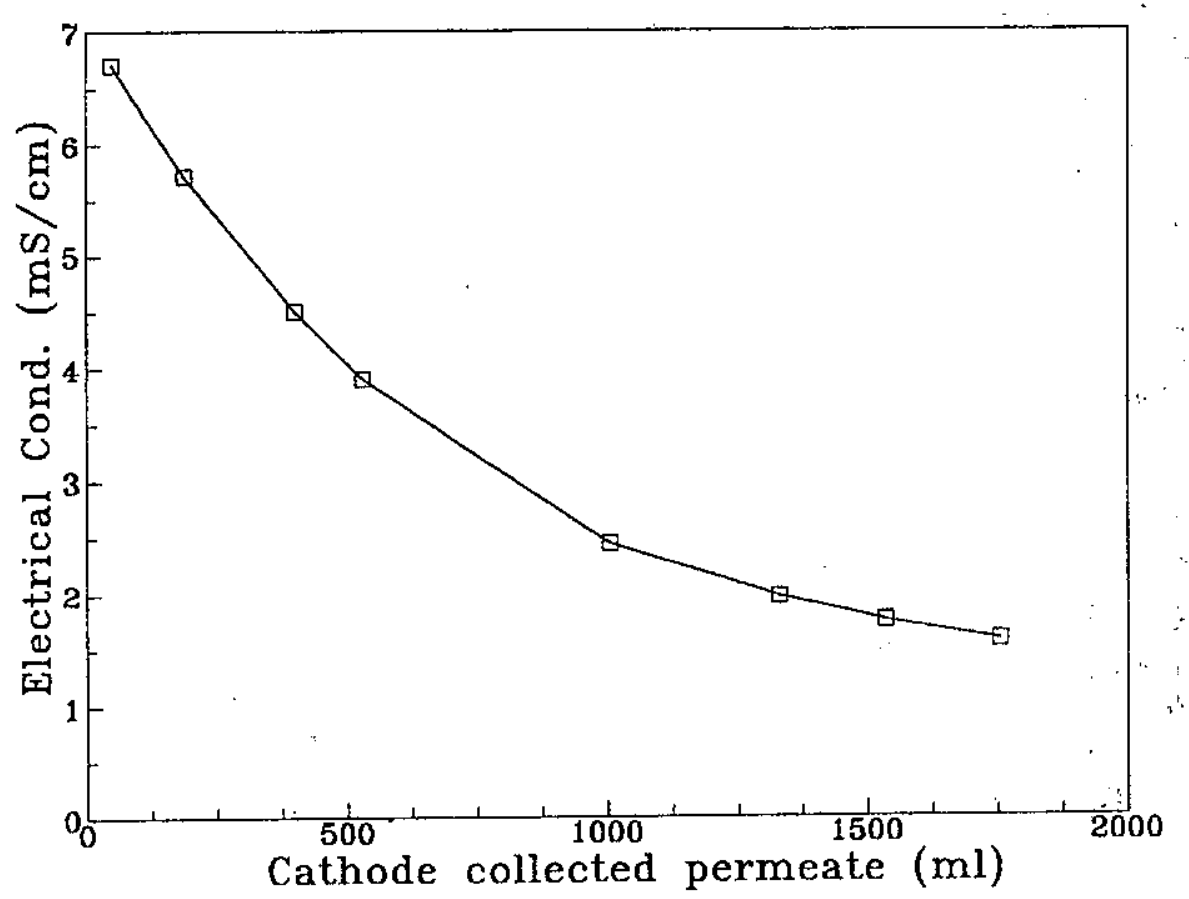

Figure 3 Electrical conductivity variation with collecte cathodic effluent

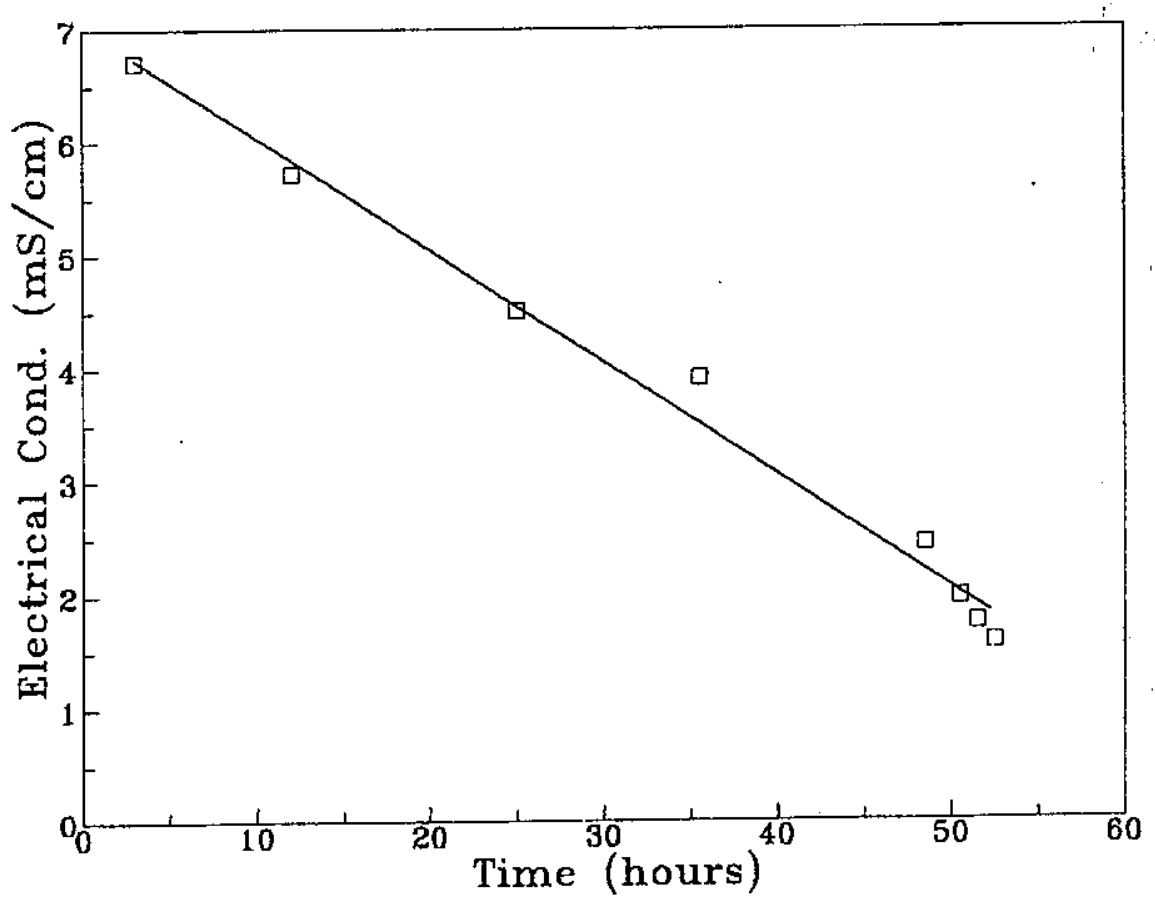

Figure 4 Flectrical conductivity variation with time of current application 


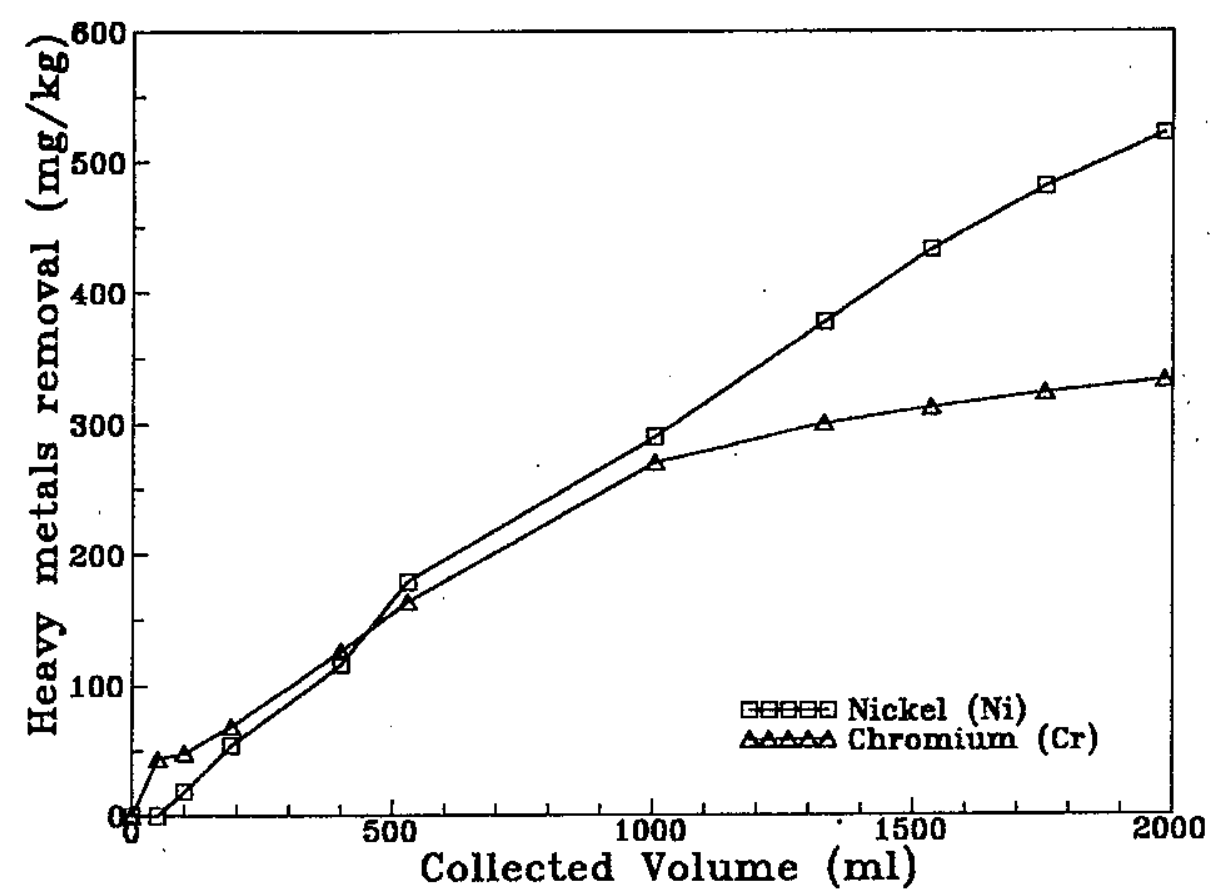

Figure $5 \mathrm{Ni} \& \mathrm{Cr}$ concentrations in the cell effluent

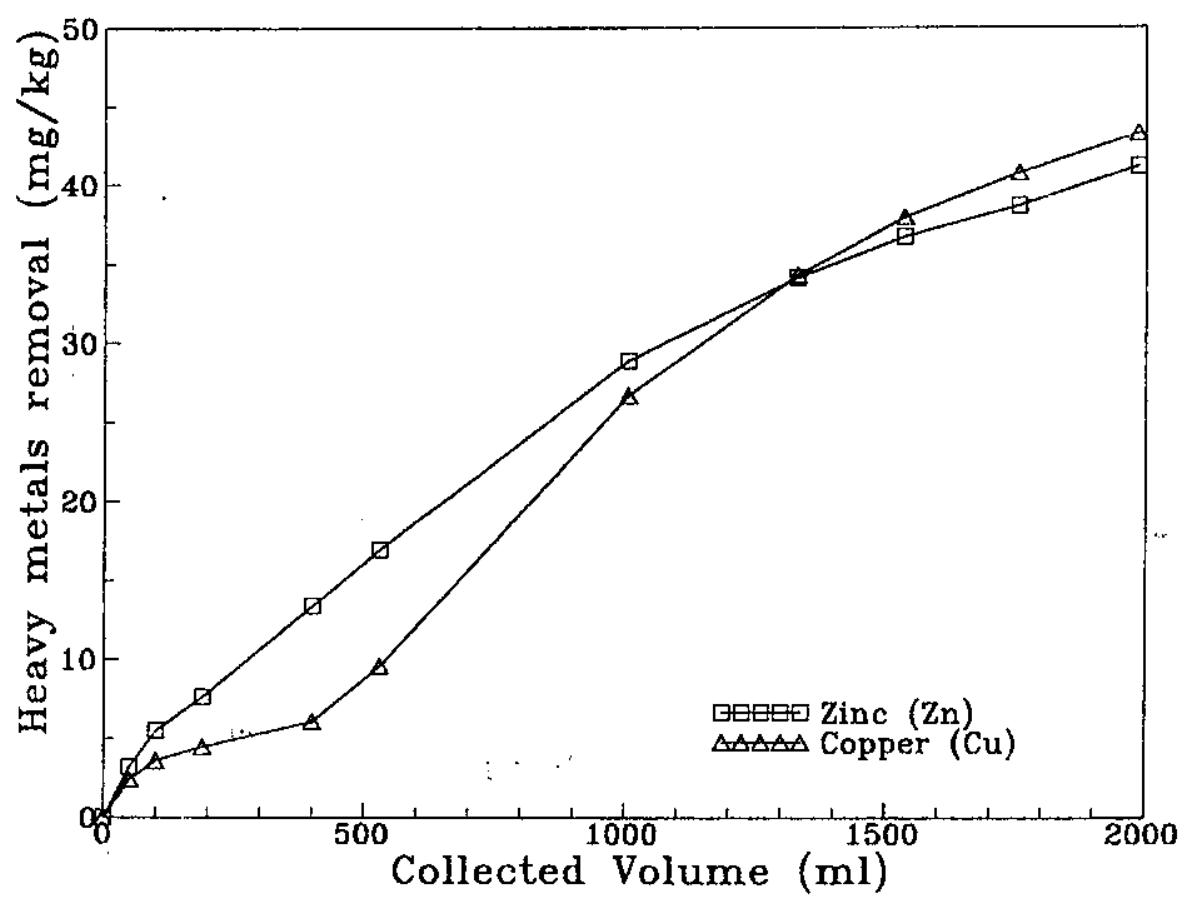

Figure $6 \% \mathrm{n}$ \& $\mathrm{Cu}$ concentrations in the cell eflluent 


\section{إزالة المعادن الثقيلة من الحسأة تصت تأثير التيار الكهريى}

د. حازم إيراهيم صالح' د.عبدالمحسن أنسى محمد'

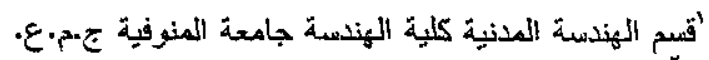

كتسم المهندة المدنية كلية التهندسة جامعة ماكجيل كندأ

\section{ملخص}

تم استخدام الثيار الكهربى المستمر لاختبـار إمكانيـة إزالـة المعسادن التقيلة مـن الحمأة

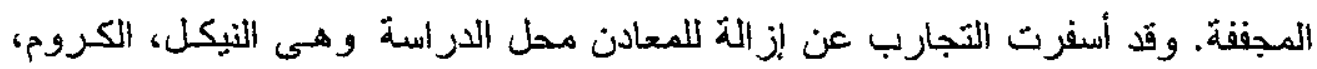

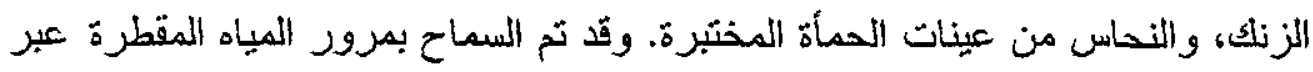

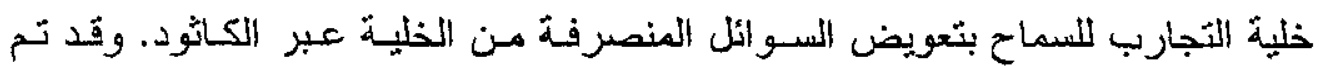

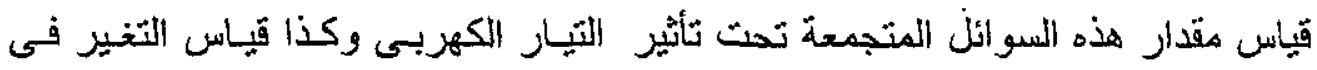

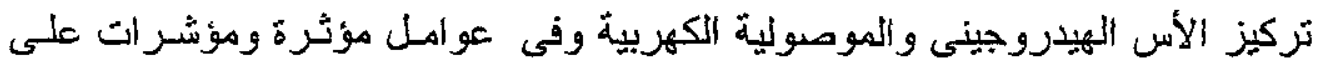

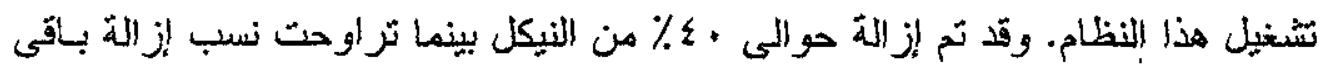

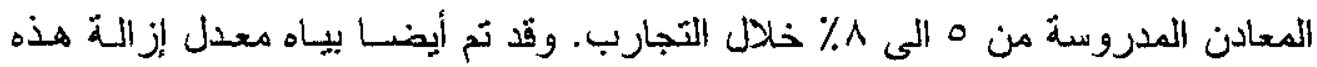
المعادن ومعدل استهلاك اللثيار الكهربى تحت ظروف هذه الإختبار أت. 